\title{
El Espejo y la Mentira, dos Cuentos de Borges y Bioy Casares
}

\author{
I \\ "El LENGUAJE REALMENTE USADO POR LOS HOMBREs": \\ UNA PERSPECTIVA HISTÓRICA
}

Las colaboraciones tempranas de Jorge Luis Borges y Adolfo Bioy Casares (alias H. Bustos Domecq o B. Suárez Lynch) son, además de obras paco menos que desconocidas, un desafío lingüístico casi insuperable.* Sin embargo, en el contexto de la literatura actual, en el medio lingüístico de Günter Grass o Catlo Emilio Gadda, definen una posición artística ante una realidad social opresiva. El lenguaje literario empleado por Borges y Bioy es una derivación del Romanticismo (aun. que es el opuesto de lo que querían crear los románticos), del ambiente estético que indujo a Wordsworth a decir, en "Preface to Lyrical Ballads," (1800):

* Obras de ficción escritas por Jorge Luis Borges y Adolfo Bioy Casares.

Bustos Domeca, H. Seis problemas para don Isidro Parodi, "Palabra liminn de Gervasio Montenegro" (Buenos Aires, 1942).

Bustos Domecq. H. Dos fantasías memorables (Buenos Aires, 1946). Contiene dos relatos: "El testigo" y "El signo".

Suárez Lynch, B. Un modelo para la muevte, "A manera de prólogo de H. Bustos Domecq" (Buenos Aires, 1946).

Bustos Domecq, H. "El hijo de su amigo", Número, No 19 (Montevideo, abriljunio, 1952), pp. 101-119.

Bustos Domecq. $\mathrm{H}$. "De aporte positivo", Buenos Aires literaria, año II, N" 17 (Buenos Aires, febreto de 1954), pp. 61-64.

Bustos Domecq, H. "La fiesta del Monstruo", Marcha (Montevideo, 30 de septiembre de 1955), pp. 20-21, 23.

Borges, Jorge Luis y Bioy Casares, Adolfo. "Los orilleros" y "El paraíso de los creyentes" (Buenos Aires, 1955). Los dos guiones llevan la fecha 20 de febrero de 1950.

Borges, Jorge Luis y Bioy Casares, Adolfo. Crónicas de Bustos Domecq (Buenos Aires, 1967). 
The principal object, then, proposed in these poems was to choose incidents and situations from common life, and to relate them, throughout, as far as was possible in a selection of language really spoken by men, and, at the same time, to throw over them a certain coloring of imagination, whereby ordinary things should be presented to the mind in an unusual aspect, and further, and above all, to make these incidents and situations interesting by tracing in them, truly though not ostentatiously, the primary law's of our nature: chiefly, as far as regards the manner in which we associate ideas in a state of excitement. ${ }^{1}$

Wordsworth limita lo que él llama el "language really used by men" diciendo que "The language, too, of these men has been adopted (purified indeed from what appears to be its real defects, from all lasting and rational causes of dislike or disgust) because such men hourly communicate with the best objects from which the best part of language is originally derived;" Wordsworth está tratando de encontrar un lenguaje poético más natural, más conversacional, más familiar que el que había predominado en la poesía lírica desde Petrarca, pero su experimento culminará en la prosa con precisamente aquellas "lasting and rational causes of dislike or disgust", que él quiso evitar.

Wordsworth deseaba modificar el vehículo expresivo de la poesía, pero en realidad abolió todas las estructuras que habian servido de guías exteriores al acto de escribir. Mientras que Wordswowrth, y todos los primeros románticos, trataron de rejuvenecer la poesía usando el lenguaje de su realidad, también, a propósito o no, invirtieron los criterios tradicionales para juzgar un poema. De un golpe destruyeron el canon que había establecido reglas objetivas para todas las artes e impusieron la subjetividad crítica.

La relación entre el artista y su público resultó entonces problemática. Durante la era pre-romántica, debido en parte al papel de la literatura en una sociedad todavía no dominada por el mercado internacional, había otra jerarquía de valores literarios: la relación entre la obra y el público fue más importante estéticamente que la expresión individual. El éxito o el fracaso de la obra de arte podía determinarse si la obra había alcanzado o no la meta que debió alcanzar según su género: una tragedia tenía que producir ciertos efectos en el público, una comedia otros. Estas palabras de M. H. Abrams sobre la poesía romántica defi-

1 William Wordsworth, The Poetical Works of William Wordsworth, ed. E. de Selincourt (Oxford, 1940-1949), II (1944, pp. 386-387). 
nen lo que cambió durante el romanticismo en la relación entre arte, artista y público:

The paramount cause of poetry is not, as in Aristotle, a formal cause, determined primarily by the human actions and qualities imitated; nor, as in nco-classic criticism, a final cause - the effect intended upon the audience; but instead an efficient cause- the impulse within the poet of feelings and desires sceking expression, or the compulsion of the "creative" imagination which, like God the creator, has its internal source of motion. ${ }^{2}$

El pasado literario se ha transformado en una ironía. El decoro existía: los personajes nobles de una tragedia hablaban y se comportaban de una manera, y los personajes vulgares de una comedia de otra. Shakespeare podía mezclar los niveles de dicción en sus dramas, para horror de los críticos neoclásicos del xviII, pero aun así, sus figuras hablaban en el lenguaje medido, controlado del verso. Había normas; había formas apropiadas en el fondo estético, y el artista (en particular en el Renacimiento) podía provocar placer en su público violentando a propósito aquellas reglas.

Otra cosa que el Romanticismo no intentó cambiar pero que sí cambió fue el papel comunicativo del lenguaje literario. La comunicación fue la primera razón para escribir en lengua vulgar cuando el latín ya no servía como medio efectivo de comunicación, ${ }^{3}$ y este paso creó simultáneamente un público y todo un mundo nuevo de posibilidades literarias. Dante, ${ }^{4}$ que establece las normas para los que siguen, tenía en cuenta un sentido de decoro basado en parte en el lenguaje cuando llamó a su poema una "Comedia" y a la epopeya virgiliana una "Tragedia". El italiano de Dante podía expresar lo noble y lo grosero en términos apropiados, y todavía hoy es un lenguaje fácilmente accesible a los estudiantes de literatura italiana. ¿Escogió él por casualidad el dialecto que vino a ser el italiano "standard", o habia ya en los tiempos de Dante un tipo de italiano en que hablaban las clases altas, lo que las diferenciaba de las clases inferiores que hablaban en dialectos locales? La pregunta puede parecer académica, pero hay que notar que cinco

2 M. H. Abrams, The Mirror and the Lamp (New York, 1958), p. 22.

3 Ver: Erich Auerbach, Literatursprache und Publikum in der lateinischen Spätantike und im Mittelaltor (Bern, 1958). Auerbach estudia la dialéctica entre cultura clásica y cultura cristiana, junto con la transición del latín como lenguaje iiterario a los lenguajes vulgares.

4 Ver: Divina Comedia, "Inferno", XX, los versos 111-113 y el décimo pátrafo de la carta de Dante a Can Grande de la Scala. 
siglos después de Dante, Alessandro Manzoni sentía la obligación de "purificar" el lenguaje de su gran novela purgándola de localismos y armonizándola con el lenguaje de la Toscania.

Cuando el latín dejó de ser el lenguaje literario de Occidente, en los distintos países europeos aparecieron lenguajes literarios que reflejaban la manera de hablar de las clases altas. Todo localismo resultó grotesco, como lo demuestra la novela del siglo XIX. Un novelista como Scott incluiría el lenguaje local en algunas escenas para dar coor local, pero la "norma" lingüística sería una forma neutra de francés, el inglés o el español. El público literario esperaba esto, y había poca razón para destruir este eslabón precioso, basado en la necesidad de comunicación, entre artista y público. El siglo xIx desterró al artista, pero siguió ha. blando su lenguaje.

La apariencia del lenguaje local en la literatura de nuestra época, aunque tiene sus raíces en el Romanticismo, no puede atribuirse a ninguno de los "ismos" de los últimos ciento cincuenta años. El Simbolismo puede haber creado del glosario del lenguaje ordinario un medio expresivo muy especial, ${ }^{5}$ pero no está de ninguna manera relacionado con el lenguaje vulgar. El Surrealismo puede haber inventado su propia técnica expresiva, la escritura automática, pero ejemplos típicos de la literatura surrealista, Les cbamps magnetiques o Nadja, o no tienen ninguna relación con formas ordinarias del discurso, o son parte de él. El lenguaje de Flaubert o de Zola puede incluir frases en argot, pero, otra vez, estas formas sirven para dar la impresión de verosimilitud, y no constituyen una gran porción de la narrativa. El uso en gran escala de jerga en cualquier obra no produciría más realismo porque este lenguaje no es en realidad el lenguaje del lector, sino una manera de hablar limitada a una clase que está, por definición, excluida del acto literario.

La clase social representada por el lenguaje literario de la mayoria de las obras novelísticas antes de la Segunda Guerra Mundial se encontraría de acuerdo con por lo menos un aspecto de las obras que leería, aunque no estuviera de acuerdo con su descripción de la sociedad o su tendencia ideológica. Los lectores de las obras de Céline o de Carlo Emilio Gadda o de las colaboraciones de Jorge Luis Borges y Adolfo Bioy Casares, sin embargo, se encuentran en conflicto con el lenguaje de sus narraciones. En las obras de éstos, no se usan modos de hablar

5 Ver: Stéphane Mallarmé, "Le mystère dans les lettres", Quant au livre (Paris, 1926): aparece en Variations sur un sujet, p. 386, en las obras completas publicadas por la Bibliothèque de la Pléiade (Paris, 1965). 
locales para dar verosimilitud a los textos; no hay nada bonito en la jerga de Céline, ni hay nada del "cuadro de costumbres", en el lunfardo de las obras de Borges y Bioy Casares. Tampoco bastaría decir que todos estos autores están trabajando dentro de los límites del "ironic mode", "A mode of literature in which the characters exhibit a power of action inferior to the one assumed to be normal in the reader or audience,..."3 La forma vulgar del lenguaje hablado no se usa necesariamente para retratar a un grupo de personajes que está socialmente, económicamente y políticamente bajo el nivel del lector y del narrador. El lenguaje de las clases bajas y del hampa ha adquirido una estatura que lo ha liberado de connotaciones de clase aunque éstas puedan estar presentes) y ha enriquecido simultáneamente la esfera de la ironía literaria.

El fenómeno no deja de tener antecedentes: El latín del Satiricón, el lenguaje poético usado por los poetas del trobar clus o la literatura escrita deliberadamente en argot en Francia son todos posibles antecedentes. Sin embargo, la relación entre el autor y el público en estas obras o géneros, o la relación entre un autor como Teófilo Folengo, el autor de la epopeya macarrónica el Baldus, y sus lectores son casos excepcionales. Allí el lenguaje literario es un lenguaje secreto, un lenguaje privado, entendido por un grupo especial de lectores. El valor social da una lengua secreta no es tan grande como la destrucción de nexos tradicionales entre lector y narrador que ahora está en movimiento. La apariencia de argot en las novelas representa un obstáculo para quien está fuera del ambiente de este argot; es así como la literatura del siglo $\mathrm{xx}$ y la de algunas épocas pasadas sí tienen algo en común. Es también verdad que el lector que viene desde afuera tiene que trabajar más en la lectura de ciertos textos que en el pasado y que su trabajo no es cl mismo que, por ejemplo, el desciframiento de pasajes de Finnegan's Wake. El lector está enajenado, y la importancia de esta enajenación excede a la del lector que se hubiera impacientado leyendo la mezcla de latín e italiano en el Baldus.

Un problema más grave en la consideración de esta literatura es que el lector tiene que buscar las intenciones del autor. Otra vez, la estética pos-romántica no permite esta clase de especulación, ya que la obra de arte es autónoma, libre del artista y sus propósitos al escribirla. Y sin embargo, el uso de un tipo de lenguaje que está deliberadamente conectado a un momento histórico específico o un lenguaje, como el de Valle-Inclán en Tirano Banderas, que pretende parodiar la jerga de

${ }^{6}$ Northrop Frye, Anatomy of Criticism (Princeton, 1957), p. 366. Se referirá a este libro como Frye. 
todo un continente en un momento dado exige que el crítico considere la obra a la luz de circunstancias extra-literarias. La jerga, ¿es actual, es la misma clase de lenguaje empleada por la gente en el momento de la publicación de la obra (Céline), o es la jerga tomada del pasado, un lenguaje muerto (Cortázar) ? También, ¿qué clase de personajes habla el lenguaje? ¿Son intelectuales burgueses, como en Rayuela, son auténticos miembros de las clases bajas como en "El hijo de su amigo" de Borges y Bioy Casares, o es el origen social de los personajes de poca importancia, como en Quer pasticciacio brutto de la via Merulana de Carlo Emilio Gadda? ¿Es el lenguaje una máscara cómica, irónica detrás de la cual un autor solemne discute ideas serias, o es una tentativa de alcanzar un nuevo nivel de realismo o naturalismo, como en Last Exit to Brooklyn de Hubert Selby?

Lo que impide la contestación de estas preguntas es que las soluciones son diferentes en cada caso, que las circunstancias que influyeron en la escritura de la obra o las circunstancias descritas en la obra tienden a ofrecer una "apología" diferente para el lenguaje de cada obra. Valle-Inclán es un gran satírico social; Tirano Banderas no es sólo una parodia lingüîstica, sino también una sátira político-social aplicable no sólo al Nuevo Mundo sino también a España. El uso de su lenguaje extremadamente vulgar en gran escala es irónico y satírico, pero la obra en que aparece este lenguaje será un misterio hasta que se identifique la cosa parodiada. Solamente si el lenguaje se entiende como una metáfora, solamente si las situaciones descritas en la obra se entienden como simbólicas, será comprensible el gesto verbal implicado por el argot o jerga. La mezcla de dialectos empleada por Carlo Emilio Gadda, el lenguaje que él usa como narrador y el lenguaje hablado por sus personajes puede ser un eco del teatro italiano en dialecto, pero la intención de Gadda es de recrear el ambiente de 1927, de delinear una situación que incluye una sociedad entera y de presentarle al lector un juicio sobre la historia en la forma de una novela: La obra, en contraste con las intenciones declaradas de Balzac, ${ }^{7}$ pretende no solamente presentar la historia de un período, sino también revelar el significado secreto de aquel período.

La situación pública que Balzac veía como la substancia de su obra tenía para él un valor intrínseco. Para Gadda, la historia se revela en una serie de imágenes, y él pretende capturar estas imágenes y dejar que el lector penetre, hasta cierto punto, sus misterios. Si el tiempo y

7 Honoré de Balzac, "Avant-propos", I, La Cómédie Humaine (Paris, 1965), p. 52. 
la historia para Balzac existen como cosas en el sentido aristotélico, existen como la manifestación fenoménica de verdades más grandes para Gadda. La situación histórica entonces se tiñe de lo arquetípico, con el valor metafórico que tienen las situaciones en $E l$ asno de oro, o las Confesiones de San Agustín. Se establecen tramas rituales, y las vidas novelescas se tuercen para ajustarse a esas tramas simbólicas. Por eso no hay nada extraño en el hecho de que la novela detectivesca y la novela de aventuras muchas veces prestan la estructura básica de estas obras. El lenguaje de, por ejemplo Quer pasticciacio..., tan real en su vulgaridad, es en realidad el primer signo que el lector está entrando en el mundo de gestos y signos, en la exploración irónica del mundo del escritor. Tampoco puede haber duda sobre por qué en muchas de estas obras, en particular en el $V$ de Thomas Pynchon o el Quer pasticciacio..., la búsqueda termina en confusión, temor y misterio.

Este punto de vista es esencialmente neo-platónico de las circunstancias sociales, de la historia misma, es necesariamente irónico cuando aparece en el contexto de la novela. Corresponde al momento en que el artista ya no puede considerar el mundo que le rodea como real en sí mismo. La palabra realidad ya no es más que otra ironía porque lo que sucede no es real. La vida carece de valor intrínseco, y lo que le sucede a una persona es o totalmente insignificante o es un drama que representa los mensajes, comprensibles sólo parcialmente, de un poder superior.

La novela siempre ha sido un monumento a la fe del artista en la historia, pero al mismo tiempo, existen géneros que tienden hacia lo simbólico, lo metafórico, lo arquetípico. El cuento, por ejemplo, casi siempre mantiene una relación tangencial con la historia. Esto ocurre, quizás, porque el cuento es la consecuencia o amalgama de otras formas de narrativa: la anécdota, el enigma, el cuento de hadas y otras. E1 cuento, tal como lo conocemos, casi siempre recuerda un tipo básico narrativo ${ }^{8}$ que tiende a colorear su mise en scéne. Por eso, la irrupción de lo fantástico en el contexto del cuento no debe representar un problema para el lector habituado al realismo literario; un cuento determinado puede parecerse a un cuento de hadas o una fábula y puede incorporar lo irreal como una convención. Sin embargo, cuando las convenciones de la literatura de fantasía y el lenguaje del realismo se mezclan, nuevos niveles de ironía se crean, $y$, de una manera ambigua, la sociedad que produjo el lenguaje se tiñe de irrealidad.

8 Ver: André Jolles, Eznfache Formen (Tübingen, 1968). Primera edición, 1930. 
La sátira es lo que une orgánicamente la colaboración más temprana de Borges y Bioy Casares: Seis problemas para don Isidro Parodi (1942).$^{10}$ Este libro, publicado bajo el seudónimo H. Bustos Domecq, ${ }^{11}$ parodia el cuento detectivesco, en particular los de G. K. Chesterton en torno al Padre Brown y los creados por Poe sobre Auguste Dupin. En esta serie, el detective, a diferencia del metafísico racional de Chejterton o el lógico melancólico de Poe, es un barbero encarcelado. Los cuentos son de intención expresionista y recuerdan las deformaciones grotescas que se encuentran en las abras de Georg Kaiser, Bertolt Brecht, y Alexander Döblin o las pinturas de Ludwig Kirchner en el sentidi de que mientras satirizan un asunto particular (el género detectivesco), pretenden ir más allá de éste para satirizar toda la sociedad argentina.

En 1946, Borges y Bioy Casares publican Dos fantasias memorables: y Un modelo para la muerte. ${ }^{13}$ Este último es una continuación de los relatos burlescos en que aparece Isidro Parodi, aunque en formato más extenso. Su autor es un discípulo de Bustos Domecq, B. Suárez Lynch, y el prólogo mordaz de Bustos Domecq abre otro campo para la sátira, el mundo literario. Dos fantasías memorables, por Bustos Domecq mismo, contiene dos milagros grotescos: en el primero, la Trinidad aparece sentada en un sillón de mimbre en un sótano de la ciudad de Buenos Aires, y en el segundo, una visión bíblica de una tierra de abundancia aparece detrás de un hombre que acaba de salir de la prisión, donde estuvo por haber publicado pornografía. El tono satírico de la primera colaboración se continúa en Dos fantasías memorables y Un models para la muerte, pero si los autores hubieran dejado de publicar sus colaboraciones en ese momento, éstas sólo habrían sido interesantes hoy

${ }^{9}$ Jorge Luis Borges y Adolfo Bioy Casares, seud. H. Bustos Domecq, "El hijo de su amigo", Nímero, No 19 (Montevideo, abril-junio, 1952), pp. 101-119. Se citará el número de la página en que aparecen las citas.

10 Jorge Luis Borges y Adolfo Bioy Casares, seud. H. Bustos Domecq, Seis troblemas para don Isidro Parodi (Buenos Aires, 1942).

11 En "Autobiographical Notes", The New Yorker (New York, Septembet 19,1970 ), en la página 87, Borges explica el origen de los nombres H. Bustos Domecq y B. Suárez Lynch, ambos derivados de nombres de antepasados de los dos autores. Esta larga nota autobiográfica está reproducida en el volumen The Aleph and Other Stories 1933-1969 (New York, 1970).

12 Jorge Luis Borges y Adolfo Bioy Casares, seud. H. Bustos Domecq, Dos fantasias memorables (Buenos Aires. 1946).

13 Jorge Luis Borges y Adolfo Bioy Casares, send. S. Suárez Lynch, Un modelo para la muerte (Buenos Aires, 1946). 
como curiosidades lingüisticas donde la sátira social se mezcla con lo fantástico. Los caprichos de dos autores en general más "serios".

Pero a partir de 1946, la sátira se hace política, y quizás esto explica por qué Borges y Bioy Casares continuaron usando seudónimos y un estilo cada vez más oscuro. Dos textos, "El hijo de su amigo" y "La fiesta del Monstruo,"14 a causa de la fuerza de su parodia, son muy importantes para entender la situación del intelectual argentino durante la dictadura de Perón. Habría que notar también que "La fiesta del Monstruo", que data de 1947, circulaba en manuscrito antes de publicarse en el Uruguay en 1955, y que "El hijo de su amigo", también publicado en el Uruguay, en 1962, lleva la fecha 21 de diciembre de 1950. "El hijo de su amigo", quizás la mejor, en términos literatios, de todas las colaboraciones, representa la culminación de un estudio del ambiente sórdido, celinesco que para los autores caracteriza la Argentina contemporánea.

La edición original de 'El hijo de su amigo', lleva un prefacio de Emir Rodríguez Monegal intitulado "Sobre una mitología". Esta introducción presenta el cuento a la luz de una tradición argentina particular, la visión idealizada de Buenos Aires que, según el crítico, ha pasado por tres etapas históricas: La primera se personifica en la figura de Macedonio Fernández, la presencia del xIx, una mezcla de "Caudillos y tertulias literarias", que eclipsaba la noción de Buenos Aires como gran metrópoli. Esta visión pronto fue reemplazada por otra, la del mundo urbano del tango, donde la "Gran aldea" llegó a ser la gran ciudad industrial. La tercera etapa es una idealización satírica o negativa que somete los valores inflados de las primeras dos etapas a un escrutinio honesto que revela todas sus injusticias, todos sus defectos. Para Rodríguez Monegal "El hijo de su amigo" es una acusación, una demostración cáustica de la corrupción de la vida en la capital argentina. Después de decir que la anécdota del cuento es trivial, añade:

Pero lo que importa es el tratamiento. A través del lenguaje se da todo: la miseria moral, la vileza, el ridículo, quedaban expresados en el giro que utiliza el relator, en su vocabulario, en sus preferencias sintácticas. Una comicidad explosiva, el ridículo abie:to del asunto. Ella denuncia otra forma, más íntima, más necesaria del porteñismo. (99-100)

14 Jorge Luis Borges y Adolfo Bioy Casares, seud. H. Bustos Domecq, "La fiesta del Monstruo", Marcha (Montevideo, 30 de septiembre de 1955), pp. 20-21, 23. Se citará el número de la página en que aparecen las citas. 
El lenguaje, visto desde esta perspectiva, es un paso hacia el realismo, un realismo, sin embargo, de que el cuento, a causa de sus tendencias hacia lo grotesco y lo caricaturesco, se excluye. El lenguaje es real y la acción es falsa. El lenguaje es el de una sociedad entera, presentada en una forma extrema; pero lo problemático del cuento surge con el valor satírico del personaje que emplea este lenguaje. Si el lenguaje es una sinécdoque para el idioma nacional, entonces la relación entre el protagonista, Urbistondo, y todos los otros personajes tiene que ser también una sinécdoque. Es decir, los personajes del cuento son signos, representaciones de la sociedad porteña, y el cuento, una visión grotesca, microscópica del mundo real de Buenos Aires.

El cuento en sí trata de la carrera cinemática de Urbistondo, sus maniobras e intrigas para hacer que un libreto suyo sea aceptado por el Sindicato de Operarios y Productores Argentinos, la SOPA. La trama se compone de una acumulación de contradicciones y mentiras, empezando con las primeras palabras de Urbistondo:

Usted, Ustáriz, pensará de mí lo que quiera, pero soy más porfiado que el vasco de la carretilla. Para mí, el renglón libros es una cosa y el cinematógrafo es otra. Mis novelitas serán como el matete del mono con la máquina de escribir, pero la jerarquía de escritor la mantengo. Por eso la vez que me pidieron una comedia bufa para la SOPA (Sindicato de Operarios y Productores Argentinos) les rogué por favor que se perdieran un poquito en el horizonte. Yo y el cinematógrafo... isalga de ahí! No ha nacido el hombre que me haga escribir para el celuloide (p. 13).

Pero en realidad nadie le pidió a Urbistondo que escribiera un libreto. El supo que había un concurso de libretos, y escribió uno, con el título original "¡Terminaron casándose!" La descripción de cómo Urbistondo trata de convencer a uno de los oficiales de la SOPA, Farfarello, que tiene el mejor libreto, merece citarse:

Créame una vez en Ia vida, Ustáriz: soy todo un impulsivo cuando conviene. Engolosinado, me lo apestillé a Farfarello: lo obsequié una gaseosa que consumimos sotto la vigilancia del cebú; le calcé un medio Toscanini en el morro y me lo llevé, en un placero, entre cuentos al caso y palmaditas, al Nuevo Parmesano de Godoy Cruz. Para preparar el estómago, embuchamos hasta sapo por barba; después tuvo su hora el minestrón; después nos dimos por entero al desgrase del caldo; después, con el Barbera, se nos vino 
el arroz a la Valenciana, que medio lo asentamos con un Moscato y así nos dispusimos a dar cuenta de la ternerita mechada, pero antes nos dejamos tentar por unos pastelones de albóndiga y la panzada concluyó con panqueques, fruta mezzo verdolaga, si usted me entiende, un queso tipo arena y otro baboso, y un cafferata-express con mucha espuma, que mandaba más gana de afeitarse que de cortarse el pelo. En ancas del espumoso cayó el señor Chissotti en persona en su forma de grappa, que nos puso la lengua de mazacote y yo la aproveché para dar una de esas noticias bomba, que hasta el camello de la joroba se cae de espaldas. Sin gastarme en prólogos ni antesalas, me lo preparé suavito, suavito a Farfarello, para cortarle el hipo con la sorpresa que yo ya disponía de un argumento que sólo le faltaba el celuloide y un reparto de bufos que el día de pago la SOPA entra en franca disolución. Aprovechando que uno de tantos caramelos pegote se le había incrustado en la cavidad, que ni tan siquiera el mozo de la panera se lo consiguió del todo extraer, principié a nenatrarle grosso modo, con lujo de detalles, el argumento (pp. 14-15).

Este pasaje tipifica al cuento entero y, en particular, a Urbistondo como narrador equivoco. Primero, la fascinación con la comida, la glotoneria del narrador, y su apodo, Catanga Chica, añaden más al retrato metafórico de la vida en Buenos Aires; el proceso digestivo es el verdadero ambiente del cuento, y Urbistondo es el genus loci.

La cena, como parte de la estructura dramática del cuento, es un engaño por lo que Urbistondo realmente quiere lograr es hacerse amigo de Farfarello e informarle sobre las complicaciones de "Terminaron casándose!" su "cinejoya". La SOPA rechaza el libreto de Urbistondo, pero él, después de haber observado secretamente la lectura de los jueces, descubre una relación amorosa entre uno de los jueces, Mariana Ruiz Villalba de Anglada, y un empleado de la SOPA, Julio Cárdenas, el hijo de un hombre que le salvó la vida a Urbistondo. Primero, Urbistondo trata de extorsionar a Mariana para conseguir dinero, y cuando fracasa, trata de extorsionar a Cárdenas. Este cree que el nombre de la "dama" está en peligro, y paga a Urbistondo, aunque tiene que robar dinero a la SOPA. Cuando Urbistondo se entera del robo, se jacta de su control sobre Cárdenas y le exige más dinero. Como Cárdenas se niega a pagar, Urbistondo informa de todo a Farfarello. Cárdenas, confrontado con la acusación, se suicida. Para expresar su gratitud a Urbistondo, la SOPA acepta su obra, y así empieza su carrera en el cine. 
Al final, Urbistondo se despide de Ustáriz diciendo que tiene una cita con "la señora Mariana".

La víctima del cuento es el único hombre honesto, Julio Cárdenas. Pero su honestidad no es una virtud en el mundo de Urbistondo; es más bien una culpa. Urbistondo sabe la diferencia entre el bien y el mal, pero su moralidad se basa en el egoísmo (self-interest), en una deformación del utilitarismo del xIx. Cuando se entera de que un librets aceptado por la SOPA significa un adelanto, lo describe así: "un adelanto sustancial en metálico, que engrosaría ipso facto el fondo común de la sociedad, de la que yo tenía derecho a considerarme adherente;" (p. 14). Cuando Mariana ridiculiza sus tentativas de extorsión, Urbistondo le dice:

Scñora... yo seré un incorregible, un romántico, pero usted es una inmoral que no recompensa mi desvelo de observador. Estoy francamente desencantado y no le puedo prometer que me repondré de este golpe en un término prudencial... Sepa que yo no pensé contentarme con que usted me apoyara para la vista (se refiere a su película); encima iba a sacarle plata. Yo soñé que en ciertas esferas los valores respetaban. Me equivoqué. Salgo de esta casa como he entrado, con las manos limpias. No se dirá que he percibido un solo vintén (p. 24).

Que ella lo haya rechazado es un pecado, no la extorsión que él intenta.

Las palabras, vehículos para la expresión de ideas y valores, son para Urbistondo nada más que máscaras. Las usa para propósitos que son claros sólo para el lector, el hombre fuera del mundo de Urbistondo. El no significa nada cuando habla; las palabras solamente sirven como gestos o movimientos hacia un objeto. Su valor semántico desaparece en la duplicidad, un lenguaje más allá de las palabras.

Pero el verdadero objeto del cuento se pierde en su recapitulación, La sociedad que produjo a Urbistondo y la SOPA, el medio social, po. lítico y moral que los crió, está ausente como agente activo del cuento, pero queda, paradójicamente, como la única realidad concreta. El drama está al margen de la intención básica de la obra, y lo que es impo:tante, un retrato de la Argentina en manos de una dictadura, se mate. rializa sin que se mencione siquiera al dictador. La corrupción, el patrioterismo de seres tan viles como Urbistondo, cuya obra usa a la Argentina como fondo "porque antes hay que conocer lo nuestro" ( $p$. 17), ta putrefeacción que caracteriza al gobiẹrno de la naciọ́n, caraça 
teriza también al país, hasta el punto de que el lenguaje mismo viene a ser un espejo de la vida, una fachada que apenas alcanza a cubrir lo sórdido que está detrás. El artista, en este caso los artistas, que son habitantes de este mundo, sólo pueden expresar su actitud empleando metáforas, presentando el mundo real que se ha alejado tanto de la verdad que imposibilita el análisis racional.

\section{III}

\section{"LA Fiesta DEL MONSTRUO"}

El segundo relato importante de esta época, "La fiesta del Monstruo", es más obviamente un ataque contra el peronismo. Como "El hijo de su amigo", es también una narración en primera persona en que el narrador describe lo que ocurre antes de una demostración política en Buenos Aires. No describe "la fiesta" misma, sólo los hechos que la preceden, $\mathrm{y}$ es este hecho - curioso porque el narrador es partidario ardiente del "Monstruo"- lo que sugiere que el enfoque del cuento incluye algo más que un retrato de la época peronista. Las circunstancias que son la materia básica del relato no están presentadas por los autores como reales en sí mismas, reproducidas "científicamente", como ocurriría en la literatura de tesis. En cambio, son tratadas como algo más profundo, de importancia más trascendental.

"La fiesta del Monstruo" es a la vez un relato horrible y cómico, pero no son ni el narrador ni los hechos que éste narra los que afectan directamente al lector. Al final de la Segunda Guerra Mundial, y ciertamente en 1955, el público ya no se iba a asustar por leer lo que había visto durante las décadas de los 30 y 40 . Este espectáculo tampoco lo iba a divertir. El cuento es desimoralizador, en una manera cómica, y lo que despierta la repulsión del lector, su rabia y su vergüenza (haciéndole reír al mismo tiempo) es el lenguaje, el idioma enmarañado, barroco y grotesco de una sociedad arruinada por un fraudulento sistema político y social que ya no podía emplear el lenguaje como modo de comunicación.

Se ha dicho que el lector o crítico ideal de este texto sería un experto en Quevedo que viviera en Buenos Aires durante la era peronista porque, por una parte, su sintaxis y su estructura intelectual tecuerdan el conceptismo quevediano, y, por otta parte, su lenguaje es completamente impenetrable para alguien que no esté familiarizado con las peculiaridades lingüísticas rioplatenses. Porque no es sencillamente 
el léxico de "La fiesta del Monstruo" o "El hijo de su amigo" lo que hace difícil su lectura. El lunfardo ha creado toda una literatura y aparece en las obras de muchos autores argentinos: en Roberto Arlt o Julio Cortázar, por ejemplo, es sencillamente una jerga, pero nunca domina la obra totalmente. Aquí constituye el cuerpo lingưístico entero.

Este énfasis en el lenguaje puede sugerir que el idioma es más importante que el narrador. En realidad, el lenguaje aquí existe independientemente del personaje, en vez de ser un elemento esencial de su personalidad como pasa, por ejemplo, con los montañeses de Walter Scott. Es también verdad que no hay ninguna distinción entre el personaje y su lenguaje; se trata de una manera de hablar tan abstracta que resiste la personalización. ¿Quién es el narrador? ¿Con quién habla? Su identidad no es importante, exactamente como los hechos concretos que ocurren en la narración no son importantes en sí como historia sino como símbolos o signos.

Lo que interesa a Borges y a Bioy Casares no es un retrato "realista" de un día en la vida de un "cabecita negra". Aunque Perón es el "Monstruo", no es precisamente la dictadura lo que los autores están tratando de pintar. El "Monstruo" es algo más que un hombre, más que el dictador: es un estado en el que el mundo padece violencia, en el que todos los valores han sido invertidos. Es una visión del mundo demoníaco:

the world of the nightmare and the scapegoat, of bondage and pain and confusion; the world as it is before the human imagination begins to work on it and before any image of human desire, such as the city or the garden, has been solidly established; the world also perverted or wasted work, ruins and catacombs, instruments of torture and monuments of folly (Frye, p. 147).

Pero tampoco es una visión apocalíptica: no hay ningún signo de que un cataclismo, un desastre purificador sea inminente. Su origen literatio, visto quizá a través de los ojos del expresionismo alemán, es el infierno de Dante, la ciudad de la sinrazón, y los nombres de sus moradores son muchas veces los mismos de los diablos de Dante. Graffiacane, Cagnazzo.

"La fiesta del Monstruo" representa un mundo irreal desde una perspectiva que revela a sus habitantes como seres subhumanos y grotescos. El lector, se presume, está fuera del mundo del texto, en la posición de todo hombre razonable con respecto a cualquier sátira. Es desde su punto de vista razonable que el espectador puede vẹr exxaçamente 
el horror que es este mundo de represión. El mundo que se suele considerar interno y psicogénico en Kafka es externo y palpable en la realidad de Borges y Bioy Casares. Pero, como Kafka, ellos diluyen el horror de su visión con un humor macabro.

La técnica narrativa de "La fiesta del Monstruo" es idéntica a la de "El hijo de su amigo." En los dos relatos, un narrador habla con o apostrofa una figura apenas presente: el lector mismo se encuentra involuntariamente en esta posición a causa del carácter dramático del diálogo unilateral (como en los poemas "The Rime of the Ancient Mariner" de Coleridge o "My Last Duchess" de Browning, por ejemplo). Este recurso captura simultáneamente la atención del lector y enajena su sensibilidad, ya que está obligado a "escuchar" un fárrago de mentiras, quimeras y ultrajes.

En los dos cuentos, el narrador es un mentiroso patológico, un falluto y un sinvergüenza un poco ingenuo. En "El hijo de su amigo", como hemos visto, el narrador se sorprende cuando una señora, a la que está tratando de extorsionar, se ríe de él, y en "La fiesta del Monstruo", el narrador expresa tres veces su deseo de vender (a cualquiera) la pistola que le dio el partido que apoya con tanto ardor. Sus métodos de narración son también idénticos. En el pasaje que sigue, el protagonista de "La fiesta del Monstruo" describe la tecepción dada a su grupo cuando pasa por un barrio porteño:

¿Qué entusiasmo partidario te perdiste, Nelly! En cada foco de población muerto de hambre se nos quería colar una verdadera avalancha que la tenía emberretinada el más puro idealismo, pero el capo de nuestra carrada, Garfunkel, sabía repeler como corresponde a ese farabutaje sin abuela, máxime si te metés en el coco que entre tanto mascalzone patentado bien se podía emboscar una quintacolumna como luz, de esos que antes que usted da la vuelta del mundo en ochenta días me lo convencen que es un crosta y el Monstruo es un instrumento de la Compañía del Teléfono. No te digo niente de más de un cagastume que se acogía a esas purgas para darse de baja en el confucionismo y repatriarse a casita lo más liviano; pero embromate y confesá que de dos chichipíos el uno nace descalzo y el otro con patín de munición, porque vuelta que yo creía descolgarme del carro era patada del señor Garfunkel que me restituía al seno de los valientes (p. 20).

El pasaje se abre con una exclamación entusiasta, y este espíritu carac. terriza la primera parte de su descripción. Sin embargo, el barrio no es 
sólo pobre sino "muerto de hambre", un insulto en español y en italiano. La muchedumbre se describe como "ese farabutaje sin abuela", otra vez con una expresión italianizada que se usa como insulto. En la fase siguiente, se describe a los integrantes del grupo como "entre tanto mascalzone patentado", una vez más un insulto en italiano macarónico, unos sinvergüenzas que esconden espías capaces de difamar al "Monstruo". Entonces, el narrador cambia su enfoque para decir que algunos timoratos de su grupo se aprovecharon de la confusión, que él llama "confucionismo", para escaparse a casa. Parece estar reprochándole lo hecho, pero en la cláusula siguiente, menciona que cuando él también trató de bajarse del camión, fue devuelto a puntapiés "al seno de los valientes" por el líder-guardián del grupo.

La esencia de la técnica narrativa de este personaje puede llamarse el "término flexible". En cualquier momento, su valoración de una situación dada puede invertirse, pero, sometida a un escrutinio agudo, puede verse que esta inversión ya estaba en la idea original. Así, la muchedumbre entusiasta ya estaba muerta de hambre. Esta paradoja, entonces, se transforma paulatinamente en una condena de la muchedumbre, que a su vez se mitiga más tarde. La reacción del narrador a la idea de abandonar el grupo es también contradictoria: "Algunos débiles se aprovecharon de la confusión para escaparse, pero cuando yo traté de hacerlo, no tuve éxito". Cuando el narrador dice algo, esto no significa nada; es decir, lo que se implica en una frase se niega en la próxima.

Se podria invocar un pasaje equivalente de "El hijo de su amigo". Allí el narrador describe su reacción cuando el hijo del hombre que le salvó la vida parece un competidor potencial:

Una tarde yo estaba más contento que con el premio de la reina Victoria, cuando cayó mi amigo Julio Cárdenas. No me venga con el globo cautivo que no lo conoce, usted que siempre formó por derecho propio entre la chusma y el negraje. Haga memoria: es hijo del viejo Cárdenas, un vejete de levita rabona, que nadando a lo perto y vigilando la pipa de porcelana que adornaba el hocico, me salvó la vida hace un rato, cuando la última creciente del Maldonado. Julio, un mocito enlutado, con ojos de esos que dan gana de plantarle un termómetro, y que yo le garanto que lo miré con franca suspicacia por el vestuario baratieri y la pinta de miserable zanagoria, que si se acercaba a las grandes mecas del celuloide es con la triste idea de venderles un argumento. 
Literato habemos, me dije, y yo le hice la cruz, viendo en ese amigo sorpresa un competidor peligroso (p. 16).

Otra vez, el "término flexible": Julio Cárdenas, al principio es llamado "mi amigo" por el narrador, pero cuando el silencioso interlocutor del diálogo parece no reconocer el nombre, el narrador le dice que lo debe reconocer ya que aquel también se crió "entre la chusma y el negraje". A partir de este momento, Julio deace como hombre, desde "mocito enlutado" a "pinta de miserable zanagoria" y luego a "competidor peligroso". El término "amigo" no tiene verdadero significado para el narrador, ya que nada en su mundo tiene valor fijo. Todos sus términos son relativos, y hasta los sustantivos pueden cambiar su identidad. Todo se ve desde la perspectiva del ego, todas las cosas son, en un momento dado, o positivas o negativas. Nada es neutral, y las identidades se metamorfosean instantáneamente.

Consistente con este relativismo lingüístico es la posición siempre móvil de ambos narradores dentro de su sociedad. El narrador de "La fiesta del Monstruo" es, si se puede decir que es algo, un partidario del "Monstruo". Parece ser un "miembro del partido", con ideales nobles, y sin embargo, el lector pronto se entera de que es un hombre pequeño y gordo constantemente victimado por sus camaradas. Que los miembros del partido tienen algo en común es cierto: todos son ignorantes, maltratados-hombres que destrozan los asientos de los autobuses y que atacan a un judío solitario porque ellos son muchos y él no puede defenderse.

Pero a pesar de todo hay aquí humor. Está mezclado con el mismo lenguaje, con la misma sintaxis que genera disgusto en el lector. Produce el mismo efecto lingüístico que el teatro en yidish. Se diría que todas las manifestaciones literarias del lunfardo tienen algo cómico, algo que se revela en la retórica burlesca del siguiente pasaje. Aquí el narrador de "La fiesta del Monstruo" describe lo que ocurre cuando trata de escaparse de sus camaradas en una bicicleta:

Tu chanchito te va a hacer confidencial, Nelly; quien más quien menos ya pedaleaba con la comezón del Gran Spiantujen, pero como yo no dejo siempre de recalcar en las horas que el luchador viene enervado y se aglomeran los más negros pronósticos, despunta el delantero fenómeno que marca goal; para la patria $\mathrm{el}$ Monstruo para nuestra merza en franca descomposición, el camionero. Ese patriota que le saco el sombrero se corrió como patinada y paró en seco al más avivato del grupo en fuga. Le aplicó súbito un mensaje que al día siguiente, por los chichones todos 
me confundían con la yegua tubiana del panadero. Desde el suelo me mandé cada hurra que los vecinos se incrustaban el pugar en el tímpano. De mientras, el camionero nos puso en fila india a los patriotas, que si alguno quería desapartarse, el de atrás tenía carta blanca para atribuirle cada patada en el culantro que todavia me duele sentarme (p. 21).

El velo de términos flexibles se abre un poco aquí, y el lector puede reconocer que en las primeras palabras el narrador ya está admitiendo su miedo ( $y$ el de los otros). Esta confesión desaparece en las frases siguientes, donde afirma que cuando una situación parece grave, siempre aparece alguien que pueda asegurar la victoria: en el caso del football, el que marca el goal de victoria; en el caso del país, el "Monstruo", y en su propio grupo, el camionero. Este "patriota" detuvo la desintegración total del grupo derribando al que había huido primero y más lejos: el narrador. Después de darle una paliza, el camionero pone en fila india a todos, y manda a cada uno que detenga a puntapiés al que tiene enfrente si trata de escaparse. Cuando el narrador se refiere a "el culantro que todavía me duele sentarme", su implicación es clara. Es decir, la vanguardia heroica del partido nacional del "Monstruo" no es más que un grupo de cobardes sometidos por el miedo. Hay algo de "El gran dictador", de Chaplin, en la torpeza de los fascistas, que resulta doblemente cómica a causa de la jerga.

El hombre razonable, mientras lee esta sátira, tiene que reírse, como tiene que enojarse a causa de la extraña verosimilitud de todo lo que se muestra aquí. Este es el propósito de este cuento particular, como la sátira literaria es el propósito principal en otros textos de los mismos autores, como "De aporte positivo" (1954) o los ensayos y entrevistas falsos de Crónicas de Bustos Domerq (1967).

Para el lector actual de Borges y Bioy Casares, más importante que la parodia de la cultura argentina que está en todas estas colaboraciones, es la humanidad fundamental que impulsó a los escritores a producir "El hijo de su amigo" y "La fiesta del Monstruo". No fue una decisión puramente política, como los cuentos mismos no son obras ideológicamente comprometidas. Lo que expresan más bien es cl deseo de los autores de ver triunfar la razón en los asuntos humanos, el deseo de que los hombres se comporten como tales en vez de crear un ambiente que destruye la dignidad y que los transforma en animales.

Yale University

AlfFred J. MAC ADAM 